\title{
KEEFEKTIFAN PEMBELAJARAN DARING DI MASA PANDEMI COVID 19
}

\author{
Dian Novita ${ }^{1}$, Lin Suciani Astuti² \\ Universitas Indraprasta PGRI \\ Jl. Raya Tengah No.80, RT.6/RW.1, Gedong, Kec. Ps. Rebo, Kota Jakarta Timur, Daerah Khusus Ibukota \\ Jakarta 13760

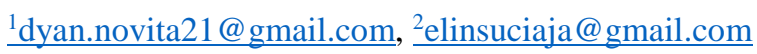

\begin{abstract}
ABSTRAK
Pembelajaran daring merupakan suatu pembelajaran yang dilakukan dengan menggunakan media internet melalui aksesibilitas, konektivitas, fleksibilitas, dan kemampuan guna memunculkan berbagai jenis interaksi dalam proses pembelajaran. Banyak sekali media pembelajaran online yang dapat dimanfaatkan dalam proses pembelajaran daring, antara lain Google Form, Google Meet, Zoom, Whatsapp, Google Classroom, edmodo, dan lains sebagainya. Tentunya media tersebut pun mempunyai kelebihan maupun kelemahan masing-masing. Tujuan dari penelitian ini adalah untuk mengetahui kefektifan pembelajaran secara daring di masa Pandemi Covid 19. Penelitian ini menggunakan model penelitian metode deskriptif. Sampel yang digunakan dalam penelitian ini adalah mahasisw/i semester 7 di Prodi Teknik Informatika Universitas Indraprasta PGRI sebanyak 58 orang. Kuisioner yang terdiri dari 20 item pernyataan, 14 pernyataan positif dan 6 pernyataan negatif. Besar skala penilaian dengan menggunakan skala likert ( 1 - 4). Berdasarkan hasil penelitian, maka pembelajaran secara daring dapat dikatakan efektif, karena jika dilihat dari persentase diagram lingkaran, mahasiswa lebih menyukai pembelajaran secara daring dengan besar persentase sebesar 84,5\%. Dan juga penggunaan media pembelajaran melalui Google Classroom juga menjadikan pilihan yang tepat karena memiliki persentase yang lebih besar di bandingkan dengan media pembelajaran online lainnya, yaitu sebesar $82,8 \%$.
\end{abstract}

Kata Kunci: Pembelajaran, Daring, Covid 19

\begin{abstract}
Online learning is learning that is carried out using internet media with accessibility, connectivity, flexibility, and the ability to bring up various types of interactions in the learning process. There are so many online learning media that can be used in the online learning process, including Google Form, Google Meet, Zoom, Whatsapp, Google Classroom, Edmodo, and so on. Of course, these media have their own advantages and disadvantages. The purpose of this study was to determine the effectiveness of online learning during the Covid 19 pandemic. This study used a descriptive method. The sample used in this study were 58 students in the 7th semester of Informatics Engineering, Indraprasta University, PGRI. The questionnaire consists of 20 statement items, 14 positive statements and 6 negative statements. The large scale of assessment uses a Likert scale (1 4). Based on the results of the study, online learning can be said to be effective, because when viewed from the percentage of pie charts, students prefer online learning with a large percentage of $84.5 \%$. And also the use of learning media through Google Classroom also makes the right choice because it has a larger percentage compared to other online learning media, which is $82.8 \%$.
\end{abstract}

Key Word: Learning, Online, Covid 19

\section{PENDAHULUAN}

Bermula dari kota yang bernama Wuhan, virus jenis baru ini telah menyebar ke berbagai belahan dunia, tidak terkecuali Indonesia. Virus ini yang menyebabkan penyakit yang disebut dengan Coronavirus disease 2019 atau yang lebih terkenal dengan nama COVID-19. Virus corona atau covid-19 merupakan keluarga besar virus yang dapat menginfeksi binatang burung dan mamalia, termasuk manusia. Menurut World Health Organization (WHO), virus ini dapat mengakibatkan penyakit mulai gejala flu ringan sampai infeksi pernapasan yang lebih parah seperti MERS-CoV dan SARS-CoV. (Ayu Kurniawati, Santosa, \& Bahri, 2020). Tentu saja, kondisi seperti ini tidak dapat di anggap remeh dan di biarkan begitu saja. Bahkan, WHO telah menetapkan pandemi Covid 19 ini sejak 11 Maret 2020 lalu.

Penyebaran virus jelas sangat berdampak pada berbagai bidang, salah satunya bidang pendidikan. Lembaga yang bergerak pada pendidikan tidak diperbolehkan untuk melakukan aktivitas belajar mengajar. 
Peraturan pemerintah telah menetapkan bahwa semua siswa dan mahasiswa belajar dari rumah. Hal ini tentu saja diharapkan dapat membantu mengurangi kegiatan interaksi banyak orang sehingga dapat menghambat penyebaran virus Covid-19. (Ningsih, 2020). Dalam proses pembelajaran semua tenaga pendidik harus menghadapi beragam tantangan untuk tetap dapat menyelenggarakan pembelajaran dengan sarana prasarana yang berbeda dan karakteristik dari peserta didik yang beragam.

Peserta didik ialah seseorang yang terdaftar dalam suatu jalur, jenjang dan juga jenis lembaga pendidikan tertentu yang selalu ingin mengembangkan potensi diri yang dimilikinya, baik terhadap aspek akademik maupun non akademik melalui suatu proses pembelajaran yang diselenggarakan pada lembaga pendidikan. (Annas, 2017)

Perguruan tinggi adalah salah satu lembaga yang terdampak dari penyebaran covid-19 setelah lembaga pendidikan pada tingkat pra sekolah, tingkat dasar, tingkat menengah pertama dan juga pada tingkat menengah atas. Perguruan tinggi dapat sebagai suatu organisasi pengelola pendidikan yang efisien. Dalam pengertian ini suatu perguruan tinggi di anggap baik jika mempunyai sumber daya dan juga dana yang tersedia, serta jumlah mahasiswa yang lewat proses pendidikannya (throughput) semakin besar. (Chanifah, 2015).

Penerapan belajar di rumah (daring) pun dilakukan oleh Universitas Indraprasta PGRI. Mahasiswa di UNINDRA sudah melaksanakan pembelajaran daring juga dari semester genap 2019/2020. Pembelajaran daring merupakan sebuah inovasi dalam dunia pendidikan yang melibatkan unsur teknologi informasi dalam pembelajaran. (Wulandari \& Agustika, 2020).

Model pembelajaran elektronik daring atau dalam jaringan atau ada juga yang menyebutnya online learning adalah suatu kegiatan pembelajaran yang memanfaatkan jaringan (internet, LAN, WAN) sebagai suatu metode dalam penyampaian materi pembelajaran, interaksi dan fasilitas serta didukung oleh berbagai bentuk layanan belajar lainnya. (Anugrahana, 2020).
Sedangkan model pembelajaran daring adalah pembelajaran yang dilakukan dengan menggunakan media internet melalui aksesibilitas, konektivitas, fleksibilitas, dan kemampuan untuk memunculkan berbagai jenis interaksi pembelajaran. (Setiono, Handayani, \& Selvia, 2020). Aksesibilitas adalah suatu hal yang dapat dijadikan akses atau hal dapat dikaitkan. (Ichlas, Dr. Hasan Basri. M.Com, \& Dr. Muhammad Arfan. SE, M.Si, Ak, 2017). Sedangkan konektivitas internet harus mendukung, demi kelancaran kegiatan pembelajaran berlangsung.

Tantangan dalam proses pembelajaran secara daring salah satunya adalah keahlian dalam penggunaan teknologi dari pihak tenaga pendidik maupun peserta didik. Ada beberapa ciri dari peserta didik dalam aktivitas belajar secara daring, sebagai berikut

1. Semangat belajar: semangat para peserta didik pada proses pembelajaran kuat atau tinggi guna pembelajaran mandiri. Ketika proses pembelajaran daring kriteria ketuntasan pemahaman materi belajar dalam suatu pembelajaran ditentukan oleh peserta didik itu sendiri. Pengetahuan akan ditemukan sendiri dan mahasiswa harus secara mandiri. Sehingga kemandirian dalam belajar tiap mahasiswa itulah yang menjadikan perbedaan hasil belajar yang berbedabeda.

2. Literacy terhadap teknologi: faktor yang kedua selain faktor kemandirian terhadap kegiatan belajar, tingkat pemahaman peserta didik terhadap pemakaian teknologi juga di butuhkan. Karena salah satu keberhasilan dalam pembelajaran daring adalah keahlian peserta didik dalam penguasaan terhadap teknologi yang akan di gunakan untuk media pembelajaran.

3. Kemampuan berkomunikasi interpersonal: kemampuan interpersonal dibutuhkan untuk menjalin hubungan dan juga interaksi antara peserta didik lainnya. Meskipun pembelajaran daring di lakukan secara mandiri tetapi pasti tetap melakukan interaksi. Jadi kemampuan interpersonal tetap harus dilatih dalam hidup bermasyarakat.

4. Berkolaborasi: memahami dan menggunakan pembelajaran interaksi dan juga kolaborasi. Peserta didik harus 
mampu berinteraksi antar peserta didik lainnya ataupun dengan dosen/pengajar pada sebuah forum yang telah disediakan. Tentunya dengan adanya pembelajaran daring juga peserta didik mampu memahami pembelajaran dengan kolaborasi.

5. Keterampilan untuk dapat belajar mandiri: salah satu karakteristik dalam pembelajaran daring adalah kemampuan dalam belajar mandiri. Ketika belajar dilakukan secara mandiri sangat di butuhkan motivasi belajar untuk menunjang suatu keberhasilan proses pembelajaran secara daring. (Handarini \& Wulandari, 2020)

Dalam pembelajaran daring ini, dosen mempunyai harapan tidak mengurangi pemahaman mahasiswa terhadap materi yang ingin di sampaikan selama perkuliahan berlangsung. Metode belajar dan media belajar juga di buat bervariatif. Dengan tujuan agar dapat mengurangi tingkat kejenuhan mahasiswa dalam menerima materi perkuliahan. Di antara manfaatnya yaitu untuk mengurangi verbalisme sehingga kegiatan belajar mengajar lebih bervariatif, informasi dari materi yang diajarkan dapat tersampaikan dengan lebih baik, dapat meningkatkan pemahaman materi pembelajaran sehingga dapat dengan mudah untuk mencapai tujuan pembelajaran. (Septiani \& Setyowati, 2020). Hal yang sangat penting dalam penerapan pembelajaran daring pada peserta didik sebaiknya memperhatikan berbagai aspek yang menunjang agar tujuan pembelajaran yang diingakan dapat tercapai. Seperti yang di kemukakan oleh (Ningsih, 2020). Hal penting itu adalah sebagai berikut :

a. Isi yang disajikan harus memiliki relevansi dengan tujuan khusus pembelajaran yang ingin dicapai oleh peserta didik.

b. Menggunakan metode - metode pembelajaran dapat melalui contoh dan latihan - latihan untuk dapat membantu belajar peserta didik.

c. Menggunakan media belajar seperti gambar- gambar dan kata - kata untuk penyajikan isi dan metode.

d. Mengembangkan dan membangun pengetahuan dan juga keterampilan baru yang sesuai dengan tujuan individu dan peningkatan organisasi.
Karena pembelajaran secara daring ini tidak menuntut peserta didik untuk hadir di dalam kelas, maka ada bermacam media pembelajaran yang di gunakan dalam pembelajaran daring cukup beragam, seperti Google Form, Google Classroom, Zoom, Google Meet, Edmodo, Quiziz dan media komunikasi seperti WhatsApp . (Pratomo \& Gumantan, 2021).

Dalam pembelajaran daring ini, haruslah adanya peran aktif antara peserta didik dan tenaga pengajar. Karena bukan hanya peserta didik yang dituntut untuk memahami materi pembelajaran ataupun media dalam pembelajaran yang di gunakan. Tetapi Pengajar (guru dan dosen) juga harus menguasai materi pembelajaran, serta teknologi untuk menunjang proses kegiatan pembelajaran secara daring.

Karena itu ada empat komponen penting yang mampu digunakan dalam membangun budaya belajar dengan menggunakan model pembelajaran daring. Keempat komponen itu ialah, sebagai beikut :

1. Peserta didik dituntut harus mandiri dalam proses belajar dengan berbagai pendekatan yang sesuai sehingga siswa mampu mengarahkan, memotivasi, dan juga mengatur dirinya sendiri dalam pembelajaran.

2. Pendidik harus mampu mengembangkan pengetahuan dan juga keterampilan, memfasilitasi dalam pembelajaran, memahami belajar dan hal-hal yang dibutuhkan dalam proses pembelajaran.

3. Tersedianya infrastruktur yang memadai dalam proses pembelajaran berlangsung.

4. Administrator harus kreatif serta penyiapan infrastrukur dalam memfasilitasi proses kegiatan pembelajaran. (Resnandari et al., 2021)

Kajian terdahulu mengenai efektifitas pembelajaran daring di masa pandemi Covid 19 ini pernah dilakukan oleh beberapa penelitian. Penelitian pertama mengenai Analisis Efektifitas Pembelajaran Daring dalam Menghadapi Wabah Pandemi COVID19 (Baety \& Munandar, 2021). Penelitian kedua Efektivitas Pembelajaran Daring di Masa Pandemi COVID 19 Bagi Mahasiswa Universitas PGRI Yogyakarta (Dewantara \& Nurgiansah, 2020). Namun pada penelitian sekarang ini sedikit berbeda, karena penelitian 
ini membahas segala aspek yang dapat membuat keefektifan dalam pembelajaran daring.

Berdasarkan dari keinginan informasi lebih lanjut dan menjawab beberapa pertanyaan tentang keefektifan pembelajaran daring di pandemi Covid- 19, peneliti melakukan penelitian ini. Bagaimana kesiapan para mahasiswa dalam mendapatkan model pembelajaran yang baru? Bagaimana ketrampilan penguasaan teknologi mahasiswa untuk menggunakan sarana sebagai pembelajaran daring? Adakah kendala dan bagaimana evaluasi dari persiapan pembelajaran daring? Pertanyaan tersebut akan terjawab dalam hasil penelitian ini. Hal ini dapat dijadikan seagai dasar untuk pelaksanaan pada proses pembelajaran di tahun akademik berikutnya. Penelitian ini mmepunyai tujuan untuk mengetahui keefektifan pembelajaran daring di masa Pandemi Covid 19.

\section{METODE PENELITIAN}

Jenis penelitian ini adalah penelitian deskriptif. "Penelitian deskriptif adalah suatu proses pemecahan masalah yang diselidiki dengan cara menggambarkan keadaan subyek dan obyek penelitian pada saat sekarang berdasarkan fakta-fakta yang nampak atau kondisi eksisting"(Fisu, 2016).

Instrument kuisioner efektifitas pembelajaran daring selama pandemi covid-19 yang digunakan dalam penelitian ini adalah sebanyak 20 butir pernyataan yang valid dari 32 pernyataan yang sudah diujikan. Dan hasil uji reliabelnya pun adalah reliable dengan hasil alpha cronbach nya yaitu 0,887 .

Hasil instrumen yang digunakan ialah kuisioner yang terdiri dari 20 item pernyataan, 14 pernyataan positif dan 6 pernyataan negatif. Besar skala penilaian dengan menggunakan skala likert ( $1-4)$. Sampel dalam penelitian ini ialah mahasiswa semester 7 prodi Teknik Informatika Universitas Indraprasta PGRI tahun akademik 2020/2021 sebanyak 58 orang yang sedang menjalani perkuliahan secara daring. Instrumen kuesioner dalam penelitian ini bertujuan untuk dapat mengetahui seberapa efektif pembelajaran daring yang diterapkan pada prodi Teknik Informatika selama Pandemi
Covid-19 terutama ingin melihat persentase media online yg digunakan selama pembelajaran daring misalnya google classroom, edmodo, whatsapp grup, youtube, zoom dan google meet(Ningsih, 2020).

Untuk pengolahan data, dilakukan dengan cara mengelompokkan data hasil kuesioner sesuai dengan variabel penelitian, mencari nilai rata-rata persentase pada setiap pernyataan positif dan negatif yang ada pada kuisioner tersebut. Dan mencari berapa persenkah mahasiswa menyukai media online yg digunakan mereka dalam belajar.

\section{HASIL DAN PEMBAHASAN}

Selama pandemi covid-19 pembelajaran dilakukan secara daring, responden atau para mahasiswa paling banyak menghabiskan waktu dalam sehari dengan mengerjakan tugas-tugasnya untuk semua mata kuliah. Aktivitas lain yang mereka lakukan adalah bermain handphone. Mereka mengatakan mereka tidak dapat menahan diri bermain handphone karena dalam mengerjakan tugas mereka menggunakan handphone dan juga laptop. Jadi, pada saat jeda mengerjakan tugas itulah mereka main games, atau menggunakan media sosial untuk sekedar chatting dengan temannya.

Berdasarkan survei melalui google form yang dilakukan mulai awal semester ganjil ini, diperoleh beberapa data mengenai keterlaksanaan, hambatan, penggunaan media online atau platform, respon jika pembelajaran secara daring diperpanjang, perbandingan antara minat pembelajaran daring dan pembelajaran tatap muka. Berdasarkan data dari kuesioner, diperoleh informasi bahwa $100 \%$ mahasiswa yang melaksanakan proses pembelajaran daring pada semester ganjil 2020/2021.

Berikut data hasil kuisioner yang didapatkan berdasarkan survey kepada para mahasiswa semester 7 tahun akademik 2020/2021.

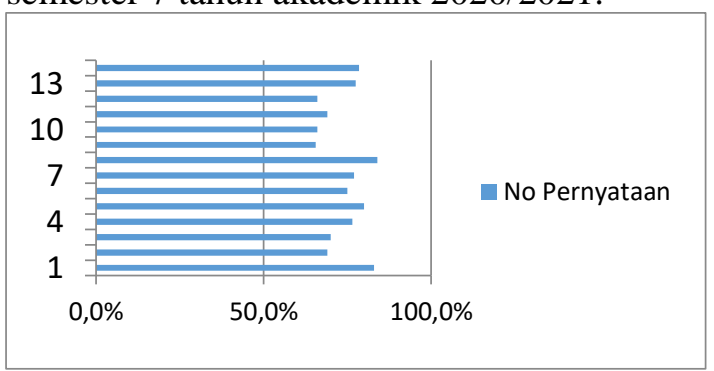

Gambar 1. Data Hasil Survei Kuisioner (Positif) 
Dilihat dari data yang ada, pada pernyataan positif yang menunjukkan persentase terbesar adalah pernyataan nomor 8 yaitu tentang perkuliahan secara daring dapat diakses dengan sangat mudah dimanapun berada. Hal ini menunjukkan bahwa para mahasiswa dalam belajar daring merasa lebih nyaman karena mereka bisa mengerjakan tugas dan mengikuti perkuliahan dimanapun mereka berada asalkan dengan sinyal internet yang memadai. Pembelajaran daring ini dapat mereka terima secara positif dengan baik.

Sedangkan dilihat dari pernyataan positif yang mendapatkan nilai persentase terendah yaitu nomor 9 yaitu tentang perkuliahan secara daring memudahkan dalam mengirim tugas tepat waktu. Hal ini dikarenakan kemungkinan mereka terlalu melambatlambatkan pengerjaan tugas yang telah diberikan oleh dosen sehingga mereka sering lalai dan terlambat dalam mengirim tugastugas mereka.

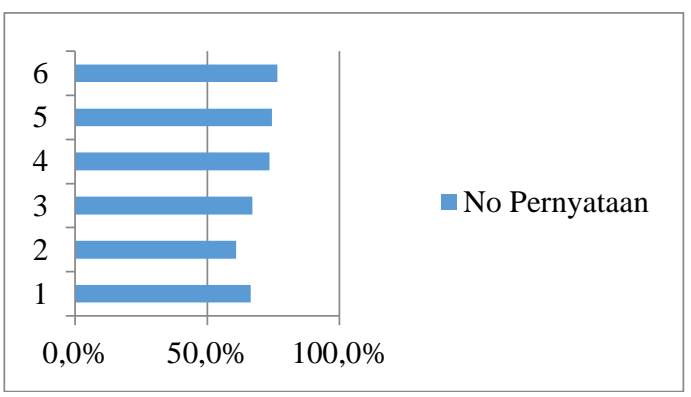

Gambar 2. Data Hasil Survei Kuisioner (negatif)

Hasil persentase yang didapat pada diagram diatas bahwa persentase terbesar yaitu sekitar $76,5 \%$ dengan pernyataannya yaitu tentang pelaksanaan perkuliahan secara daring sangat sulit diakses dengan lokasi tempat tinggal mahasiswa/i. hal ini dikarenakan mahasiswa semester 7 kemugkinan mempunyai sinyal yang kurang kuat pada daerah atau tempat tinggal mereka masing-masing.

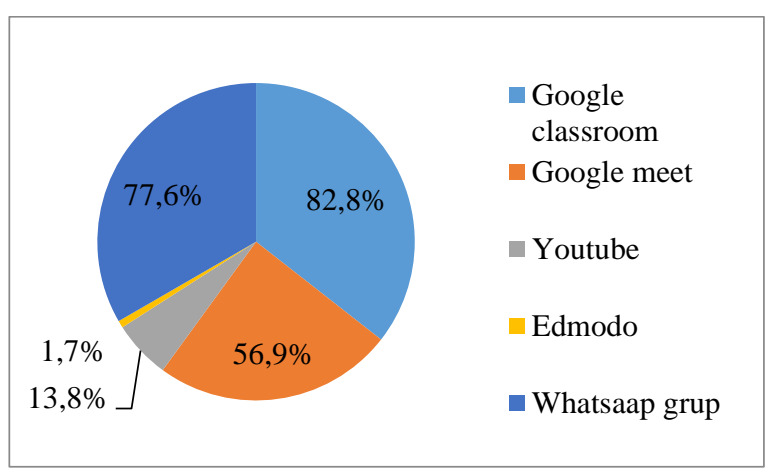

Gambar 3. Media online/platform yang digunakan pembelajaran daring
Berdasarkan item kuesioner selanjutnya, diperoleh sebuah informasi mengenai media online yang paling banyak diminati/disukai oleh mahasiswa pada kegiatan pembelajaran daring melalui media online google classroom sebanyak $82,8 \%$. Kemudian yang kedua ada $77,6 \%$ mahasiswa menyukai Whatsapp, 13,8\% mahasiswa menyukai Youtube dan sisanya 1,7\% menyukai Edmodo.

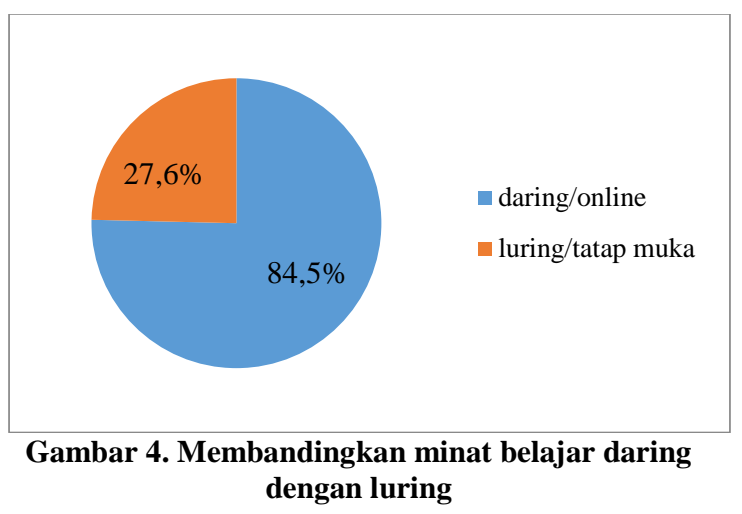

Hasil persentase pada diagram lingkaran diatas bahwa pembelajaran daring mendapatkan $84,5 \%$ sedangkan pembelajaran luring hanya sisanya yaitu $27,6 \%$.

\section{SIMPULAN DAN SARAN}

Berdasarkan hasil penelitian diatas maka dapat di simpulkan bahwa pembelajaran secara daring dapat dikatakan efektif, karena jika dilihat dari persentase diagram lingkaran, mahasiswa lebih menyukai pembelajaran secara daring dengan besar persentase sebesar $84,5 \%$. Dan juga penggunaan media pembelajaran melalui Google Classroom juga menjadikan pilihan yang tepat karena memiliki persentase yang lebih besar di bandingkan dengan media pembelajaran online lainnya, yaitu sebesar $82,8 \%$. Saran untuk penelitian selanjutnya dapat lebih membahas dari kemampuan guru dalam pembalajaran daring.

\section{DAFTAR PUSTAKA}

Annas, A. N. (2017). Manajemen Peserta Didik Berbasis Kecerdasan. Manajemen Pendidikan Islam, 5(2), 132-142.

Anugrahana, A. (2020). Hambatan, Solusi dan Harapan: Pembelajaran Daring Selama Masa Pandemi Covid-19 Oleh Guru Sekolah Dasar. Scholaria: Jurnal Pendidikan Dan Kebudayaan, 10(3), 282-289. https://doi.org/10.24246/j.js.2020.v10.i 
3.p282-289

Ayu Kurniawati, K. R., Santosa, F. H., \& Bahri, S. (2020). Sosialisasi Hidup Sehat di Tengah Wabah Virus Corona. JPMB : Jurnal Pemberdayaan Masyarakat Berkarakter, 3(1), 58-65. https://doi.org/10.36765/jpmb.v3i1.225

Baety, D. N., \& Munandar, D. R. (2021). Analisis Efektifitas Pembelajaran Daring dalam Menghadapi Wabah Pandemi COVID-19. EDUKATIF: Jurnal Ilmu Pendidikan, 3(3), 880-889.

Chanifah, N. (2015). Desain pendidikan karakter di perguruan tinggi umum. 4748.

Dewantara, J. A., \& Nurgiansah, T. H. (2020). Efektivitas Pembelajaran Daring di Masa Pandemi COVID 19 Bagi Mahasiswa Universitas PGRI Yogyakarta. Jurnal Basicedu, 5(1), 367375.

https://doi.org/10.31004/basicedu.v5i1. 669

Fisu, A. A. (2016). Analisis Dan Konsep Perencanaan Kawasan Pelabuhan Kota Penajam Sebagai Pintu Gerbang Kab. Penajam Paser Utara Kalimantan Timur. Jurnal Ilmiah Ilmu-Ilmu Teknik, 1, 125136.

Handarini, O. I., \& Wulandari, S. S. (2020). Pembelajaran Daring Sebagai Upaya Study From Home (SFH). Jurnal Pendidikan Administrasi Perkantoran (JPAP), 8(3), 465-503.

Ichlas, M., Dr. Hasan Basri. M.Com, A., \& Dr. Muhammad Arfan. SE, M.Si, Ak, C. (2017). Pengaruh penerapan standar akuntansi pemerintahan, sistem pengendalian intern pemerintah dan aksesibilitas laporan keuangan terhadap akuntabilitas keuangan pemerintah Kota Banda Aceh. Jurnal Administrasi Akuntansi: Program Pascasarjana Unsyiah, 3(4), 76-84.

Ningsih, S. (2020). Persepsi Mahasiswa Terhadap Pembelajaran Daring Pada Masa Pandemi Covid-19. JINOTEP (Jurnal Inovasi Dan Teknologi Pembelajaran): Kajian Dan Riset Dalam Teknologi Pembelajaran, 7(2), 124-132.

https://doi.org/10.17977/um031v7i2202 0p124

Pratomo, C., \& Gumantan, A. (2021). Analisis Efektifitas Pembelajaran Daring
Terhadap Hasil Belajar Pendidikan Olahraga Pada Masa Pandemi Covid-19 SMK SMTI Bandarlampung. Journal Of Physical Education, 2(1), 26-31.

Resnandari, E., Astuti, P., Baysha, H., Studi, P., Pendidikan, T., Ilmu, F., ... Korespondensi, E. (2021). Daring Di Program Studi Teknologi Pendidikan Universitas Pendidikan Mandalika. 2(3), 92-100.

Septiani, E., \& Setyowati, L. (2020). Penggunaan Media Pembelajaran Secara Daring Terhadap Pemahaman Belajar Mahasiswa. Prosiding Seminar Nasional Pascasarjana Universitas Negeri Jakarta, 121-128.

Setiono, P., Handayani, E., \& Selvia, S. (2020). Strategi Guru Dalam Pembelajaran Daring Pada Masa Covid19 Di Sekolah Dasar. JURIDIKDAS: Jurnal Riset ..., 3(3), 402-407. Retrieved from https://ejournal.unib.ac.id/index.php/jur idikdasunib/article/view/14570

Wulandari, I. G. A. A., \& Agustika, G. N. S. (2020). Dramatik Pembelajaran Daring Pada Masa Pandemi Covid-19 (Studi Pada Persepsi Mahasiswa PGSD Undiksha). Mimbar PGSD Undiksha, 8(3), 515-526. 